UNES Journal of Social and Economics Research

Volume 3, Issue 1, June 2018

P-ISSN 2528-6218

E-ISSN 2528-6838

Open Access at: http:// lppm.ojs.unespadang.ac.id/index.php/UJSER

PENGARUH EARNING PER SHARE (EPS), DEBT TO EQUITY RATIO (DER)

DAN RETURN ON EQUITY (ROE) TERHADAP HARGA SAHAM

\title{
EARNING EFFECT PER SHARE (EPS), DEBT TO EQUITY RATIO (DER) AND RETURN ON EQUITY (ROE) ON STOCK PRICE
}

\section{Sigit Sanjaya ${ }^{1}$, Susi Yuliastanty ${ }^{2}$}

1Fakultas Ekonomi, Universitas Puta Indonesia "YPTK" Padang

Email: sigitsanjaya@upiyptk.ac.id

${ }^{2}$ Fakultas Ekonomi, Universitas Ekasakti

Email: susylqu@yahoo.com

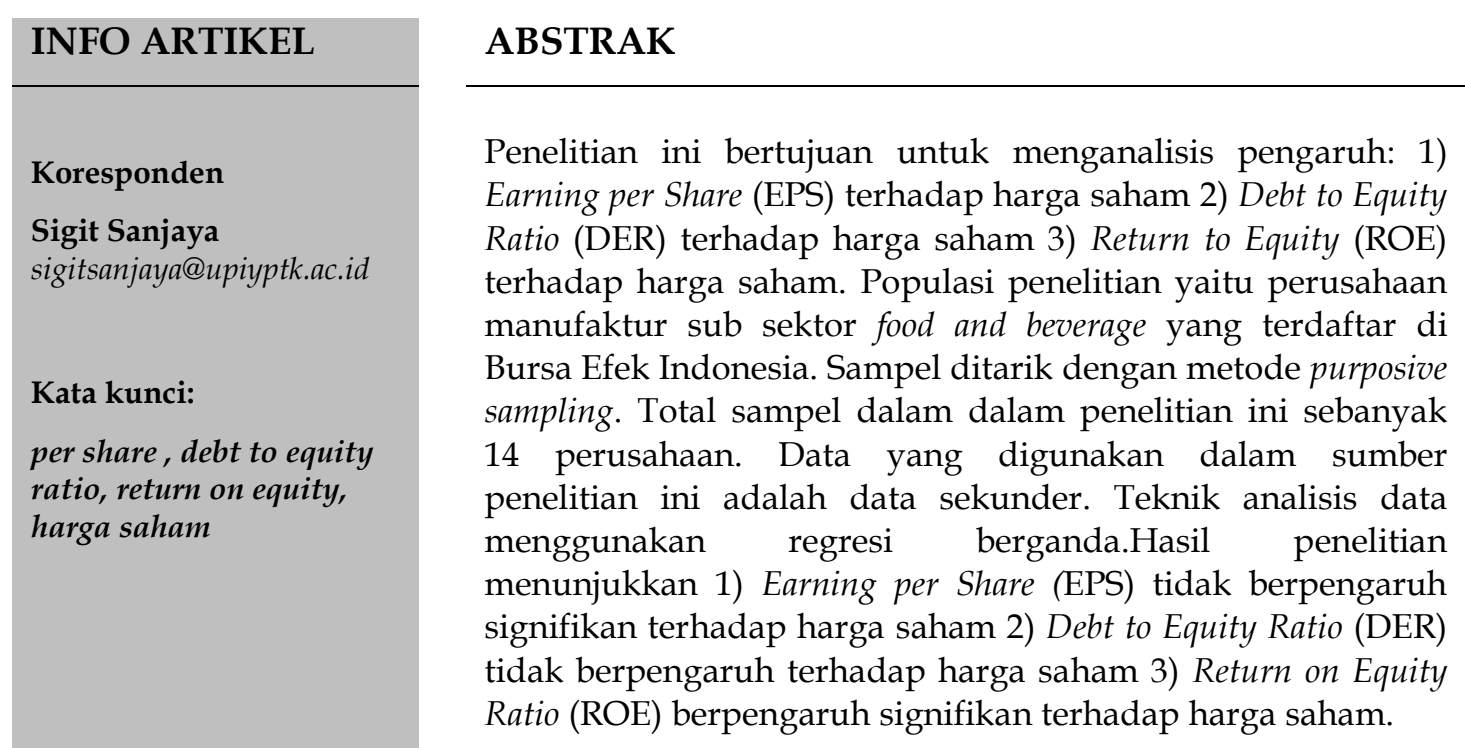

Copyright $@ 2018$ UJSER. All rights reserved 


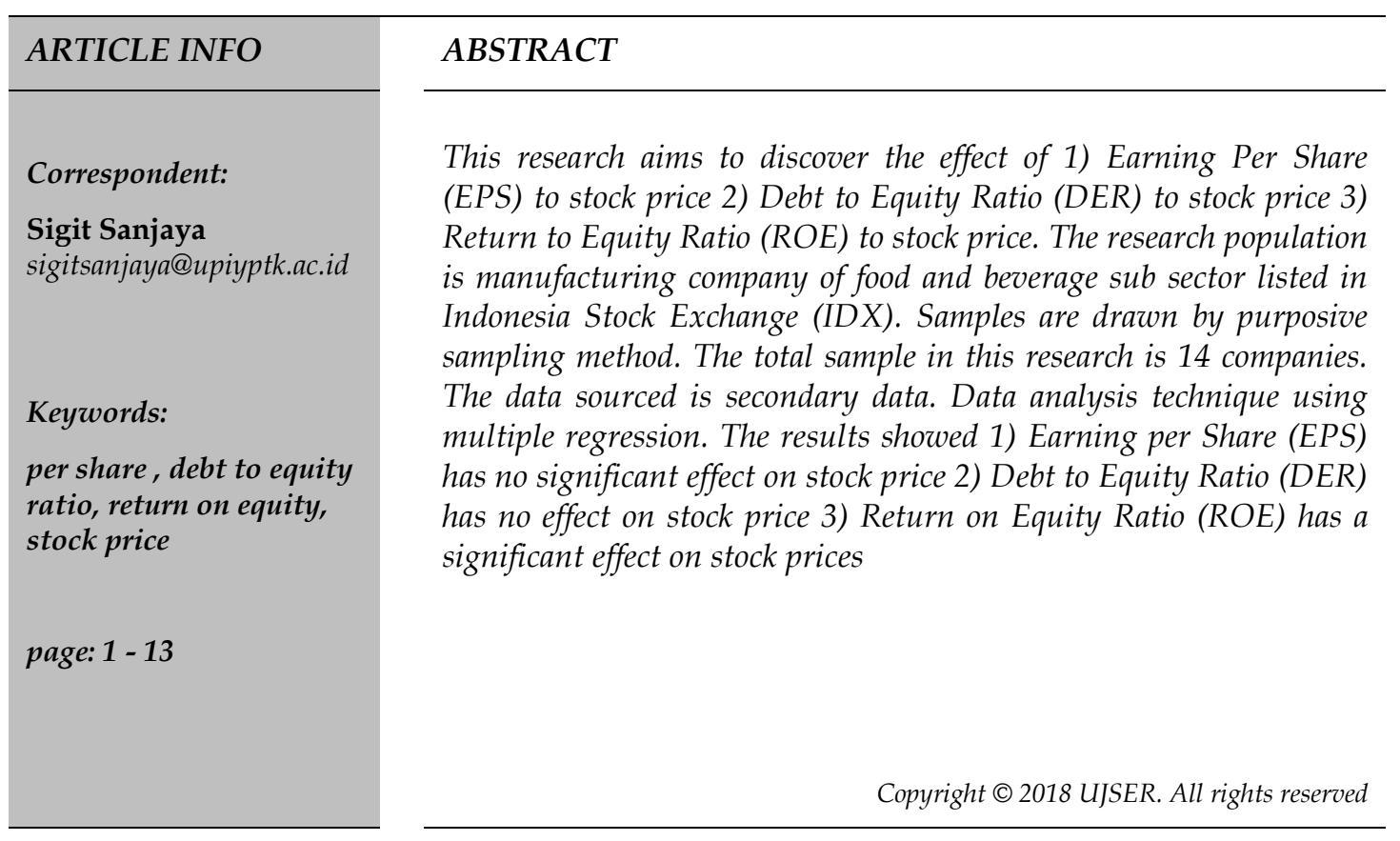

\section{PENDAHULUAN}

Arus modal lintas batas negara telah melonjak naik menjadi lebih dari dua puluh kali lipat sejak tahun 1990. Dengan makin terintegrasinya pasar keuangan, kita juga menyaksikan adanya peningkatan dalam jumlah perusahaan yang terdaftar pada berbagai efek di seluruh dunia. Beberapa dari peningkatan yang paling mengesankan justru terjadi di pasar-pasar keungan yang sedang berkembang, salah satunya di Indonesia. Pada tahun 2005, jumlah emiten yang terdaftar di Bursa Efek Indonesia (BEI) yaitu 336. Pada tahun 2017 per 12 September 2017, jumlah emiten di BEI sebanyak 555 perusahaan ("https://www.sahamok.com/perusahaan-publikterbuka-tbk-emiten-bei-bursa-efek-indonesia/," 2017).

Pasar modal mempunyai peran vital bagi perekonomian suatu negara. Oleh karena itu pemerintah selalu berupaya untuk meningkatkan peran pasar modal karena pasar modal itu sendiri merupakan salah satu sumber pembiayaan bagi perusahaan dan merupakan sarana bagi masyarakat untuk melakukan investasi. Investasi yang dilakukan oleh masyarakat akan bermanfaat bagi perusahaan maupun masyarakat itu sendiri. Bagi perusahaan (emiten) ketika menjadi perusahaan yang go public melalui pencatatan saham perdana saham (initial public offering/IPO) akan mendapatakan manfaat di antaranya: memperoleh sumber pendanaan baru, memberikan competitive advantage untuk pengembangan usaha, melakukan merger atau akuisisi perusahaan lain dengan pembiayaan melalui penerbitan saham baru, peningkatan kemampuan going concern dan meningkatkan citra perusahaan (“http:// market.bisnis.com/read/20150121/7/393242/inilah-6-manfaat-go-publicbagi-perusahaan," 2015). Bagi investor manfaat yang didapat ketika membeli saham yaitu capital gain, dividen, dan saham bonus ("https: //www.kembar.pro/2015/07/3-keuntungan-dari-berinvestasi-saham.html," 2015). 
Harga saham merupakan representasi dari nilai perusahaan. Menurut Jogiyanto (2010) harga saham merupakan harga saham yang terjadi di pasar bursa pada saat tertentu yang ditentukan oleh pelaku pasar dan ditentukan oleh permintaan dan penawaran saham yang bersangkutan di pasar modal. Jika terdapat lebih banyak orang yang ingin membeli suatu saham dari pada menjualnya, harga akan naik karena saham menjadi langka dan orang-orang bersedia membayar lebih tinggi. Di sisi lain, apabila terdapat banyak saham untuk dijual dan tidak banyak orang untuk membeli, harga akan jatuh. Dikarenakan interaksi dinamis antara penawaran dan permintaan inilah yang membuat harga saham menjadi berfluktuasi.

Terdapat berbagai faktor yang dapat mempengaruhi harga saham di pasar modal. Menurut Brigham \& Houston (2010) harga saham dipengaruhi oleh beberapa faktor, yaitu faktor internal dan faktor eksternal, contoh faktor internal yaitu pengumuman laporan keuangan, pengumuman investasi dan lain-lain, contoh faktor eksternal yaitu pengumuman dari pemerintah, pengumuman hukum dan pengumuman industri sekuritas. Menurut Sartono (2008) harga saham terbentuk di pasar modal ditentukan oleh faktor seperti laba per lembar atau earning per share, rasio laba terhadap harga per lembar saham atau price earning ratio, tingkat bunga bebas risiko yang diukur dari tingkat bunga deposito pemerintah dan tingkat kepastian operasi perusahaan.

Sub sektor Food and Beverage merupakan sub sektor yang stabil dan tidak terpengaruh oleh perubahan kondisi ekonomi karena makanan dan minuman merupakan kebutuhan yang selalu diperlukan oleh manusia. Peneliti memilih perusahaan Food and Beverage sebagai objek penelitian. Berdasarkan latar belakang yang telah diuraikan, peneliti melakukan penelitian yang berjudul "Pengaruh Earning Per Share (EPS), Debt To Equity Ratio (DER) dan Return On Equity (ROE) terhadap Harga Saham (Studi pada Perusahaan Food and Beverages yang Terdaftar di Bursa Efek Indonesia Periode 2012-2016)".

\section{Kerangka Konseptual}

Menurut Brigham \& Houston (2010) harga saham menentukan kekayaan pemegang saham diterjemahkan menjadi memaksimalkan harga saham perusahaan. Harga saham pada waktu tertentu akan bergantung pada arus kas yang diharapkan diterima di masa depan oleh investor "rata-rata" jika investor membeli saham. Sehingga dapat dikatakan bahwa harga saham adalah harga yang terbentuk sesuai permintaan dan penawaran dipasar jual beli (pasar modal) dan biasanya merupakan harga penutupan.

Jenis harga saham menurut Widiatmojo (2005) yaitu harga nominal, harga perdana, harga pasar, harga pembukaan, harga penutupan, harga tertinggi, harga terendah dan harga rata-rata. Harga nominal merupakan harga yang tercantum dalam sertifikat saham yang ditetapkan oleh emiten untuk menilai setiap lembar saham yang dikeluarkan.Harga perdana merupakan pada waktu harga saham tersebut dicatat di bursa efek atau disebut juga harga pada waktu IPO (Intial Public Offer). Harga pasar merupakan harga jual dari perjanjian emisi kepada investor, yang berarti harga pasar merupakan harga jual dari investor yang satu dengan investor 
yang lain. Harga pembukaan merupakan harga yang diminta oleh penjual atau pembeli pada saat jam bursa dibuka. Harga penutupan merupakan harga yang diminta oleh penjual ataupun pembeli pada saat akhir hari bursa. Harga tertinggi merupakan harga paling suatu saham yang terjadi pada hari bursa. Harga terendah merupakan harga saham yang paling rendah yang diperdagangkan pada hari itu. Harga rata-rata merupakan perataan harga tertinggi dan terendah suatu saham pada hari diperdagangkan tersebut.

Menurut Brigham \& Houston (2010) harga saham dipengaruhi oleh beberapa faktor utama:

1. Faktor internal

a. Pengumuman tentang pemasaran produksi penjualan

b. Pengumuman pendanaan

c. Pengumuman badan direksi manajemen (management board of director announcement)

d. Pengumuman pengambilahan diversifikasi seperti laporan investasi, laporan akuisisi.

e. Pengumuman investasi seperti melakukan ekspansi pabrik pengembangan riset dan penutupan usaha lainnya.

f. Pengumuman ketenagakerjaan (labour announcements), seperti negosiasi baru, kontrak baru dll.

g. Pengumuman laporan keuangan perusahaan.

2. Faktor eksternal

a. Pengumuman dari pemerintah seperti perubahan suku bunga tabungan dan deposito kurs valuta asing, serta berbagai regulasi yang dileuarkan oleh pemerintah

b. Penggunaan hukum seperti tuntutan terhadap perusahaan atau terhadap manajernya dan tuntutan perusahaan terhadap manajernya.

c. Pengumuman industri sekuritas.

Earning Per Share (EPS) adalah bentuk pemberian keuntungan yang diberikan kepada para pemegang saham dari setiap lembar yang dimiliki (Fahmi, 2012). Perilaku investor terhadap harga saham dipengaruhi oleh informasi laba yang dalam hal ini digambarkan oleh EPS sebagai cerminan kinerja keuangan perusahaan selama periode tertentu. EPS merupakan laba yang diperoleh perusahaan per lembar saham.Laba perusahaan merupakan alat ukur yang berguna untuk membandingkan laba suatu entitas usaha yang berbeda dan untuk membandingkan laba suatu entitas dari waktu ke waktu jika terjadi perubahan dalam struktur modal. Dengan mengetahui nilai EPS, maka dapat dinilai berapa besaran potensi laba yang akan diterima investor. Apabila investor membandingkan tingkat EPS tahun sekarang dengan tahun sebelumnya, maka akan dapat diketahui tingkat pertumbuhan, dengan demikian EPS merupakn gambaran masa depan. Semakin tinggi EPS sebuah saham, yang akan diberikan kepada pemegang saham, maka akan menambah daya tarik bagi investor untuk memiliki saham tersebut. 
Perusahaan yang stabil akan memperlihatkan stabilitas pertumbuhan EPS setiap tahunnya dan sebaliknya EPS adalah tolok ukur dimana baik manajemen maupun pemegang saham menaruh perhatian besar terhadap hal tersebut. Ketika melihat EPS, terutama jumlah lembar saham yang beredar membutuhkan ketelitian karena terkadang jumlah saham berbeda dalam satu tahun perbedaan ini disebabkan adanya penawaran saham biasa, stock split, pembayaran saham atau opsi yang digunakan. Perhitungan Earning Per Share (EPS) menurut (Tandelilin (2010) secara sistematis adalah sebagai berikut:

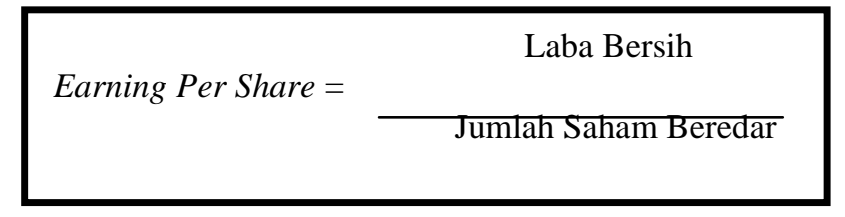

Debt to Equity Ratio (DER) merupakan rasio yang membandingkan jumlah utang terhadap ekuitas.Rasio ini lazim digunakan oleh para investor untuk melihat seberapa besar utang apabila dibandingkan dengan ekuitas yang dimiliki oleh perusahaan atau para pemegang saham. Semakin tinggi angka DER maka diasumsikan perusahaan memiliki risiko yang semakin tinggi terhadap likuiditas perusahaannya. Semakin kecil DER semakin baik bagi perusahaan dan akan meningkatkan harga saham. Menurut Kasmir (2012) Debt to Equity Ratio (DER) merupakan rasio untuk mengukur total utang dengan total ekuitas. Rasio ini dihitung dengan cara membandingkan total hutang perusahaan, termasuk hutang lancar dengan total ekuitas. Menurut Sartono (2008) makin tinggi Debt to Equity Ratio (DER) maka semakin besar risiko yang dihadapi, dan investor akan meminta tingkat return yang semakin tinggi. Rasio yang tinggi menunjukkan proporsi modal sendiri yang rendah untuk membiayai aset.Investor perlu memperhatikan Debt to Equity Ratio (DER) karena variabel ini membagi informasi mengenai besarnya utang atau kewajiban yang ditanggung oleh perusahaan. Rumus Debt to Equity Ratio (DER) menurut Kasmir (2012):

$$
\text { Debt to Equity Ratio }=\frac{\text { Total Utang (Debt) }}{\text { Ekuitas (Equity) }}
$$

Return on Equity (ROE) merupakan rasio yang mengukur efektivitas atau kemampuan perusahaan perusahaan dalam mengelola modal dari para investor untuk mendapatkan laba bersih. Menurut Brigham dan Houston (2010) rasio ini merupakan rasio yang paling penting karena pemegang sahamnya pasti ingin mendapatkan tingkat pengembalian yang tinggi atas modal yang telah diivestasikan dan Return on Equity (ROE) menunjukkan tingkat yang mereka peroleh. Rasio ini menunjukkan efisiensi modal sendiri.Semakin tinggi rasio ini, semakin baik posisi pemilik perusahaan dan begitupun sebaliknya. Return on Equity (ROE) merupakan alat analisis untuk mengukur tingkat pengembalian atas investasi pemegang saham biasa. Perusahaan yang memiliki Return on Equity (ROE) yang rendah atau bahkan 
negatif akan diklasifikasikan sebagai perusahaan yang kurang baik dalam menghasilkan laba yang menjadi laba yang menjadi hak pemegang saham.

\section{Hubungan Antar Variabel}

Earning per Share (EPS) menggambarkan perbandingan antara laba bersih dengan jumlah saham yang beredar. Semakin tinggi rasio EPS mencerminkan kinerja perushaan tersebut semakin baik.EPS dipengaruhi oleh pendapatan perusahaan. Jika pendapatan perusahaan tersebut tinggi, maka EPS juga akan tinggi, begitupun sebaliknya. Hal tersebut dapat mempengaruhi harga saham, karena harga saham pengaruh awalnya merupakan pendapatan perusahaan. Semakin tingginya permintaan investor terhadap saham perusahaan akan berimplikasi pada harga saham tersebut. Banyaknya permintaan menyebabkan harga saham menjadi naik ataupun meningkat. Semakin tinggi EPS akan meningkatkan harga saham dan tingkat returnyang diharapkan dan sebaliknya.

Debt to Equity Ratio (DER) merupakan rasio yang menunjukkan perbandingan antara pembiayaan dan pendanaan melalui ekuitas.Semakin tinggi rasio ini, maka akan semakin besar resiko yang dihadapi perusahaan. Investor tentu akan melihat resiko ini sebelum memutuskan melakukan investasi, hal ini dapat berpengaruh terhadap permintaan saham. Debt to Equity Ratio (DER) merupakan keputusan terkait pendanaan, didefinisikan sebagai keputusan yang menyangkut komposisi pendanaan yang telah dipilih oleh perusahaan.Struktur keuangan perusahaan merupakan komposisi dari keputusan pendanaan yang mencakup utang jangka pendek, utang jangka panjang dan modal sendiri. Setiap perusahaan akan mengharapkan adanya struktur modal optimal, yaitu struktur modal yang dapat memaksimalkan harga saham.

Return to Equity (ROE) atau hasil pengembalian atas ekuitas atau return on equityatau rentabilitas modal sendiri merupakan rasio untuk mengukur laba bersih sesudah pajak dengan modal sendiri. Secara umum semakin tinggi return atau penghasilan yang diperoleh perusahaan, maka akan semakin baik kedudukan pemilik perusahaan perusahaan, artinya semakin tinggi ROE berarti semakin baik kinerja perusahaan dalam dalam mengelola ekuitas yang dimiliki untuk menghasilakn return bagi pemegang saham, maka akan semakin tinggi pula minat investor untuk memperoleh saham tersebut. Minat yang tinggi terhadap saham akan menyebabkan permintaan menjadi banyak dan akan mendorong kenaikan pada harga saham tersebut.

Berdasarkan uraian di atas, maka ditarik suatu kerangka konseptual sebagai berikut:

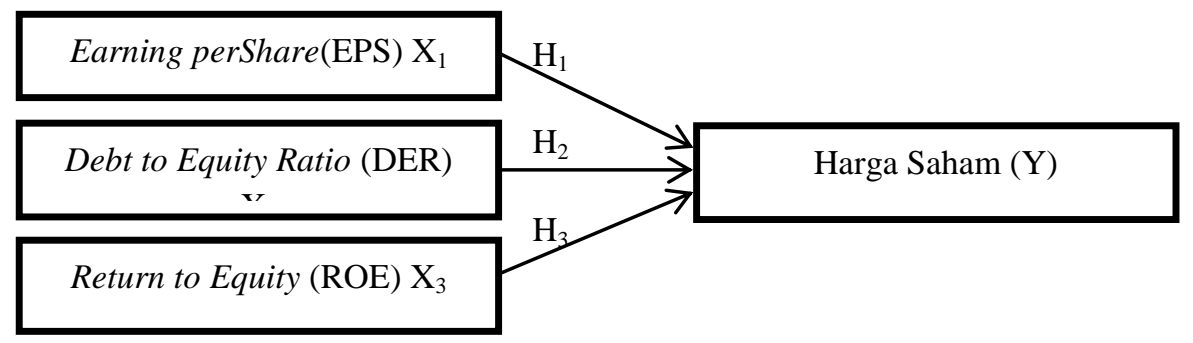

Gambar 1. Kerangka Konseptual 
Hipotesis dalam penelitian ini adalah:

$\mathrm{H}_{1}$ : Earning per Share berpengaruh signifikan terhadap harga saham.

$\mathrm{H}_{2}$ : Debt to Equity Ratio berpengaruh signifikan terhadap harga saham.

$\mathrm{H}_{3}$ : Return to Equity berpengaruh signifikan terhadap harga saham.

\section{METODE PENELITIAN}

Pendekatan penelitian yang digunakan peneliti adalah pendekatan kausalitas, dimana riet kausal merupakan riset yang memiliki tujuan utama membuktikan hubungan sebab akibat atau hubungan mempengaruhi dari variabel variabel yang diteliti. Objek dari penelitian ini adalah Perusahaan Food and Beverage yang terdaftar di Bursa Efek Indonesia. Total populasi dalam penelitian berjumlah 16 perusahaan dan dijadikan sampel sebanyak 14 perusahaan dengan teknik purposive sampling. Data penelitian yaitu data sekunder yang diperoleh dari Bursa Efek Indonesia.

Untuk menghindari penafsiran yang berbeda pada penelitian, maka perlu dijelaskan definisi operasional sebagai berikut:

1. Harga Saham

Harga saham merupakan harga penutupan pasar saham selama periode pengamatan untuk setiap jenis saham yang dijadikan sampel dan pergerakannya senantiasa diamati oleh para investor.

2. Earning per Share (EPS)

Earning per Share merupakan rasio yang menunjukkan seberapa besar keuntungan yang diperoleh investor atau pemegang saham per saham dengan cara membagi laba bersih setelah pajak dengan jumlah saham biasa yang beredar.

3. Debt to Equity Ratio (DER)

Debt to Equity Ratio merupakan rasio untuk mengukur total hutang dengan total ekuitas dengan cara membandingkan total hutang perusahaan, termasuk hutang lancar dengan total ekuitas.

4. Return on Equity (ROE)

Return on Equity merupakan rasio yang digunakan untuk mengukur efektivitas atau kemampuan perusahaan dalam mengelola modal dari para investor untuk mendapatkan laba bersih.

\section{Uji Asumsi Klasik}

Sebelum melakukan pengujian regresi, terlebih dahulu dilakukan pengujian asumsi klasik yang berguna untuk mengetahui apakah data yang digunakan telah memenuhi ketentuan dalam model regresi.

1. Uji Normalitas Residual

Menurut Ghozali (2011), uji normalitas residual dalam penelitian ini bertujuan untuk menguji apakah dalam dalam model regresi variabel pengganggu atau residual memiliki distribusi normal. Uji normalitas residual dilakukan dengan menggunakan Kolmogoraf-Smirnov test dengan pedoman pengambilan keputusan sebagai berikut:

a. Jika nilai Sig atau probabilitas $<$ dari $\alpha=0,05$ maka residual tidak berdistribusi normal.

b. Jika nilai Sig atau probabilitas $\geq$ dari $a=0,05$ maka residual berdistribusi normal. 
2. Uji Heteroskedastisitas

Uji ini bertujuan untuk menguji apakah dalam model regresi terjadi ketidaksamaan variance dari residual satu ke pengamatan lain. Dasar pengambilan keputusan pada uji heteroskedastisitas adalah:

a. Jika nilai signifikansi $>0,05$, tidak terjadi heteroskedastisitas.

b. Jika nilai signifikansi $<0,05$, terjadi heteroskedastisitas.

3. Uji Multikolinearitas

Multikolinearitas adalah situasi adanya korelasi variabel-variabel independen. Uji multikolinearitas diperlukan untuk mengetahui ada tidaknya variabel independen yang memiliki kemiripan antar variabel independen dalam suatu model.Pengujian mutikolinearitas dalam penelitian ini menggunakan Variance Inflation Factor (VIF). Adapun kriteria yang digunakan untuk pengujian ini sebagai berikut: jika nilai tolerance $<0,10$ atau sama dengan VIF $>10$, maka terdapat multikolinearitas antara variabel independen.

4. Uji Autokorelasi

Uji ini bertujuan untuk menguji apakah tidak terjadi korelasi dari satu pengamatan ke pengamatan lain yang diurutkan berdasarkan waktu. Model regresi yang baik adalah tidak terjadi autokorelasi. Data dikategorikan terbebas dari gejala autokorelasi jika nilai Durbin-Watson berada pada rentang -2 sampai dengan 2.

\section{Teknik Analisis Data}

1. Uji Koefisien Determinasi (Adjusted R Square)

Uji ini digunakan untuk mengkaji goodness-fit dari model regresi. Koefisien determinasi $\left(\mathrm{R}^{2}\right)$ mengukur seberapa jauh kemampuan model dalam menerangkan variasi model dalam menerangkan variasi variabel dependen.

2. Uji Hipotesis

a. Uji F

Uji F dilakukan untuk menguji apakah secara serentak variabel independen mampu menjelaskan variabel dependen secara baik atau untuk menguji apakah model yang digunakan telah fix, apabila nilai sig < 0,05 menunjukkan bahwa variabel independen secara bersama-sama memberikan pengaruh yang signifikan terhadap variabel dependen.

b. Uji t dilakukan untuk menguji apakah secara terpisah variabel independen mampu menjelaskan variabel dependen secara baik, dengan ketentuan jika nilai sig $<0,05$ dan nilai $t_{\text {hitung }}>t_{\text {tabel }}$ maka hipotesis diterima.

\section{HASIL DAN PEMBAHASAN}

Objek dalam penelitian ini adalah perusahaan manufaktur industri barang konsumsi sektor food and beverage yang terdaftar di BEI dalam periode 2012-2016. Berdasarkan Hasil penelitian diperoleh dari data kuantitatif yang bersumber dari data sekunder. Sumber data yang digunakan merupakan sumber data sekunder yang diperoleh dengan mengambil data yang dipublikasi oleh BEI (Bursa Efek Indonesia) maupun oleh emiten. 


\section{Hasil Uji Asumsi Klasik}

1. Uji Normalitas Residual

Uji normalitas digunakan untuk menguji apakah distribusi sebuah residual mengikuti atau mendekati distribusi normal. Untuk melihat normalitas residual dapat dilakukan dengan metode kolmogrov smirnov pada $a=0,05$. Dari hasil pengolahan data SPSS terlihat pada Tabel 1.

Tabel 1. Uji Normalitas

\begin{tabular}{llr}
\multicolumn{2}{c}{ One-Sample Kolmogorov-Smirnov Test } \\
\hline & & \multicolumn{1}{c}{$\begin{array}{c}\text { Unstandardized } \\
\text { Residual }\end{array}$} \\
\hline $\mathrm{N}$ & Mean & 14 \\
Normal Parametersa & .0000000 \\
& Std. & $2.41435066 \mathrm{E} 3$ \\
& Deviation & .202 \\
Most Extreme Differences & Absolute & .202 \\
& Positive & -.131 \\
& Negative & .757 \\
Kolmogorov-Smirnov Z & & .615 \\
Asymp. Sig. (2-tailed) & &
\end{tabular}

a. Test distribution is Normal.

Dari hasil pengujian, terlihat bahwa nilai Asymp.Sig (2-tailed) sebesar 0.615 lebih besar dari 0,05, sehingga data dikategorikan berdistribusi normal.

2. Uji Heteroskedastisitas

Uji heteroskedastisitas digunakan untuk melihat apakah dalam sebuah mdel regresi terjadi ketidaksamaan varians dari residual atas pengamatan ke pengamatan lain. Untuk mendeteksi adanya heteroskedastisitas digunakan uji Gletser. Hasil pengujian terlihat pada Tabel 2.

Tabel 2. Uji Heteroskedastisitas

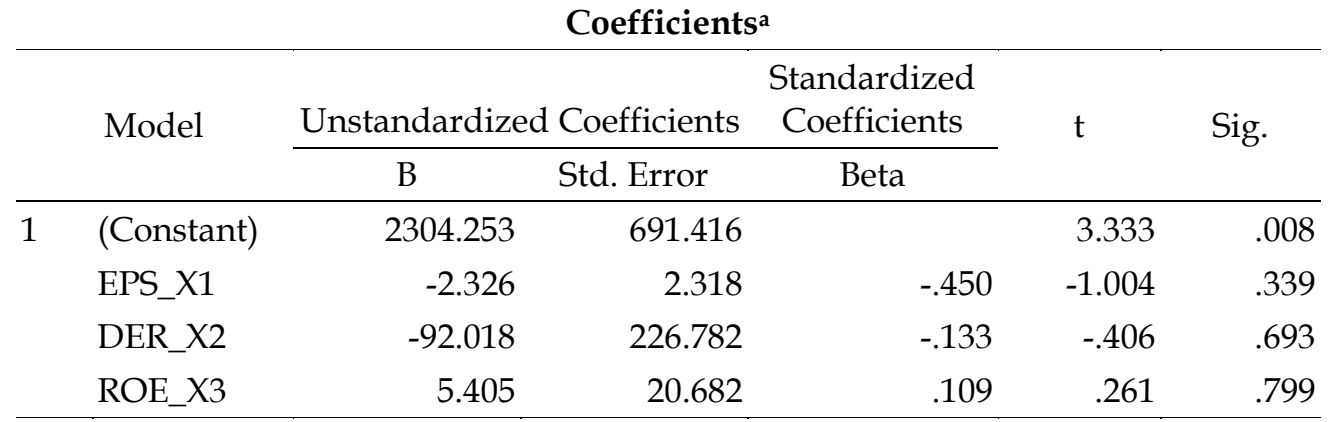

a. Dependent Variable: ABS_RES

Dari hasil pengujian, terlihat bahwa nilai sig variabel EPS, DER, ROE > 0,05, sehingga dapat dikategorikan bahwa data telah terbebas dari gejala heteroskedastisitas.

3. Uji Multikolinearitas

Model regresi yang dinyatakan bebas dari multikolinearitas apabila VIF $<10$ dan tolerance $>0,1$. Hasil pengujian multikolinearitas terlihat pada Tabel 3 . 
Tabel 3. Uji Multikolinearitas

\begin{tabular}{cccc}
\multicolumn{4}{c}{ Coefficients $^{\mathbf{2}}$} \\
\hline \multirow{2}{*}{ Model } & \multicolumn{2}{c}{ Collinearity Statistics } \\
\cline { 3 - 4 } & & Tolerance & VIF \\
\hline 1 & EPS_X1 & .982 & 1.019 \\
& DER_X2 & .987 & 1.013 \\
& ROE_X3 & .994 & 1.006 \\
\hline \multicolumn{2}{c}{ a. Dependent Variable: HARGA_SAHAM_Y }
\end{tabular}

Berdasarkan hasil pengujian terlihat bahwa variabel EPS, DER, ROE terbebas dari multikolinearitas karena nilai tolerance $>0.05$ dan nilai $\mathrm{VIF}<10$.

4. Uji Autokorelasi

Model terbebas dari autokorelasi apabila nilai Durbin-Watson berada di antara -2 dan 2. Pengujian autokorelasi terlihat pada Tabel 4.

Tabel 4. Uji Autokorelasi

Model Summary ${ }^{b}$

\begin{tabular}{lrrrrrr}
\hline Model & R & R Square & $\begin{array}{l}\text { Adjusted R } \\
\text { Square }\end{array}$ & $\begin{array}{l}\text { Std. Error of } \\
\text { the Estimate }\end{array}$ & \multicolumn{2}{c}{$\begin{array}{l}\text { Durbin- } \\
\text { Watson }\end{array}$} \\
\hline 1 & $.746^{\mathrm{a}}$ & .556 & .423 & 2752.78329 & 1.094 \\
\hline
\end{tabular}

a. Predictors: (Constant), ROE_X3, DER_X2, EPS_X1

b. Dependent Variable: HARGA_SAHAM_Y

Dari hasil pengujian terlihat bahwa nilai Durbin-Watson sebesar 1,094, berada pada rentang -2 dan 2. Dapat disimpulkan bahwa model telah terbebas dari autokorelasi.

\section{Regresi Berganda}

1. Uji Koefisien Determinasi

Uji Koefisien determinasi Adjusted R Square yang dilakukan terlihat pada Tabel 5.

Tabel 5. Uji Koefisien Dererminasi

\begin{tabular}{lrrrr}
\multicolumn{5}{c}{ Model Summary } \\
\hline Model & R & R Square & $\begin{array}{c}\text { Adjusted R } \\
\text { Square }\end{array}$ & $\begin{array}{c}\text { Std. Error of } \\
\text { the Estimate }\end{array}$ \\
\hline 1 & $.746^{\mathrm{a}}$ & .556 & .423 & 2752.78329 \\
\hline a. Predictors: (Constant), ROE_X3, DER_X2, EPS_X1 &
\end{tabular}

Besarnya angka Adjusted $R$ Square adalah 0,423 atau 42,3\%. Hal ini mengindikasikan bahwa keterlibatan variabel bebas yaitu EPS, DER dan ROE terhadap variabel terikat yaitu Harga saham sebesar 42,3\%. Sedangkan sisanya sebesar $57,7 \%$ dipengaruhi oleh variabel lain yang tidak diteliti dalam penelitian ini.

2. Uji F

Berdasarkan pengolahan data dengan SPSS, hasil uji F terlihat pada Tabel 6. 
Tabel 6. Uji F

\begin{tabular}{rlrrrrr}
\multicolumn{7}{c}{ ANOVA $^{\mathbf{b}}$} \\
\hline & Model & Sum of Squares & df & Mean Square & F & Sig. \\
\hline 1 & Regression & $9.495 E 7$ & 3 & $3.165 \mathrm{E} 7$ & 4.177 & $.037 \mathrm{a}$ \\
& Residual & $7.578 \mathrm{E} 7$ & 10 & 7577815.814 & & \\
Total & $1.707 \mathrm{E} 8$ & 13 & & & \\
\hline
\end{tabular}

a. Predictors: (Constant), ROE_X3, DER_X2, EPS_X1

b. Dependent Variable: HARGA_SAHAM_Y

Dari hasil pengolahan terlihat bahwa nilai sig sebesar 0,037 $<0,05$ dan nilai $F_{\text {hitung }}$ lebih besar dari $\mathrm{F}_{\text {tabel, }}$ di mana $4.177>2,62$. Berdasarkan Tabel 6, dapat dilihat bahwa model yang digunakan sudah fix, sehingga dapat dilanjutkan pada uji hipotesis atau uji $\mathrm{t}$.

\section{Pengujian Hipotesis}

Pengujian hipotesis dilakukan dengan membandingkan (a) $t_{\text {hitung }}$ dengan $t_{\text {tabel }}$ (b) nilai sig dengan a yang diajukan yaitu $95 \%$ atau $a=0,05$. Berdasarkan nilai $t_{\text {hitung }}$ dan nilai signifikansi yang diperoleh, maka didapat hasil pengujian hipotesis pada Tabel 7.

\begin{tabular}{|c|c|c|c|c|c|c|}
\hline \multicolumn{7}{|c|}{ Tabel 7. Uji t } \\
\hline & \multirow[t]{2}{*}{ Model } & \multicolumn{2}{|c|}{ Unstandardized Coefficients } & \multirow{2}{*}{$\begin{array}{c}\begin{array}{c}\text { Standardized } \\
\text { Coefficients }\end{array} \\
\text { Beta }\end{array}$} & \multirow[t]{2}{*}{$\mathrm{t}$} & \multirow[t]{2}{*}{ Sig. } \\
\hline & & B & Std. Error & & & \\
\hline \multirow[t]{4}{*}{1} & (Constant) & 674.884 & 1348.203 & & .501 & .627 \\
\hline & EPS_X1 & 3.813 & 3.547 & .229 & 1.075 & .308 \\
\hline & DER_X2 & 66.602 & 323.615 & .044 & .206 & .841 \\
\hline & ROE_X3 & 75.943 & 23.113 & 694 & 3.286 & .008 \\
\hline
\end{tabular}

a. Dependent Variable: HARGA_SAHAM_Y

1. Pengujian Hipotesis $1\left(\mathrm{H}_{1}\right)$

Hasil dari Tabel 7, pengujian hipotesis dilakukan dengan membandingkan nilai $t_{\text {hitung }}$ dengan $t_{\text {tabel }}$ pada $\alpha=0,05$. Nilai $t_{\text {tabel }}$ adalah 2,22. Untuk variabel Earning Per Share $\left(X_{1}\right)$ nilai thitung adalah 1,075 dan nilai signifikansi 0,308. Dengan demikian dapat disimpulkan bahwa $t_{\text {hitung }}<t_{\text {tabelyaitu }} 1,075<2,22$ dan nilai sig 0,308 $>0,05$. Hal ini menunjukkan bahwa Earning Per Share (EPS) tidak berpengaruh signifikan terhadap harga saham. Sehingga Hipotesis pertama $\left(\mathrm{H}_{1}\right)$ dalam penelitian dalam penelitian ini ditolak.

2. Pengujian Hipotesis $2\left(\mathrm{H}_{2}\right)$

Hasil dari Tabel 7, pengujian hipotesis dilakukan dengan membandingkan nilai $t_{\text {hitung }}$ dengan $t_{\text {tabel }}$ pada $a=0,05$. Nilai $t_{\text {tabel }}$ adalah 2,22. Untuk variabel Debt to Equity Ratio $\left(\mathrm{X}_{2}\right)$ nilai thitung adalah 0,206 dan nilai sig 0,841. Dengan demikian dapat disimpulkan bahwa $t_{\text {hitung }}<t_{\text {tabel }}$ yaitu 0,206 $<2,22$ dan nilai sig 0,841 $>0,05$. Hal ini menunjukkan bahwa Debt to Equity Ratio (DER) tidak berpengaruh signifikan terhadap harga saham. Sehingga Hipotesis kedua $\left(\mathrm{H}_{2}\right)$ dalam penelitian dalam penelitian ini ditolak. 
3. Pengujian Hipotesis $3\left(\mathrm{H}_{3}\right)$

Hasil dari tabel 7, pengujian hipotesis dilakukan dengan membandingkan nilai $t_{\text {hitung }}$ dengan $t_{\text {tabel }}$ pada $a=0,05$. Nilai $t_{\text {tabel }}$ adalah 2,22 . Untuk variabel Return $O n$ Equity $\left(X_{3}\right)$ nilai $t_{\text {hitung }}$ adalah 3,286 dan nilai sig 0,008. Dengan demikian dapat disimpulkan bahwa $t_{\text {hitung }}>t_{\text {tabel }}$ yaitu 3,286 $>2,22$ dan nilai sig 0,008 $<0,05$. Hal ini menunjukkan bahwa Return On Equity Ratio (ROE) berpengaruh signifikan terhadap harga saham. Sehingga Hipotesis ketiga $\left(\mathrm{H}_{3}\right)$ dalam penelitian dalam penelitian ini diterima.

\section{Pembahasan}

1. Pengaruh Earning Per Share $\left(X_{1}\right)$ terhadap Harga Saham $(Y)$

Berdasarkan analisis statistik ditemukan bahwa hipotesis pertama $\left(\mathrm{H}_{1}\right)$ ditolak dan disimpulkan bahwa Earning Per Share tidak berpengaruh signifikan terhadap harga saham. Hal ini dapat dilihat dari signifikansi 0,308 (besar dari pada $\alpha=$ $0,05)$. Nilai $t_{\text {hitung }}<t_{\text {tabel }}$ yaitu $1,075<2,22$. Artinya, tidak terdapat pengaruh signifikan Earning Per Share $\left(\mathrm{X}_{1}\right)$ secara parsial terhadap harga saham $(\mathrm{Y})$. Ini berarti bahwa penelitian tidak menemukan bukti bahwa Earning Per Share $\left(\mathrm{X}_{1}\right)$ berpengaruh signifikan terhadap harga saham. Hasil penelitian ini sejalan dengan penelitian yang dilakukan oleh Nurrohman (2016) dan Sanjaya, Tomi \& Goretti (2015) yang menyatakan bahwa Earning Per Share $\left(X_{1}\right)$ tidak berpengaruh signifikan terhadap harga saham(Y).

2. Pengaruh Debt to Equity Ratio $\left(\mathrm{X}_{2}\right)$ terhadap Harga Saham $(\mathrm{Y})$

Berdasarkan analisis statistik ditemukan bahwa hipotesis $\left(\mathrm{H}_{2}\right)$ ditolak dan disimpulkan bahwa Debt to Equity Ratio (DER) tidak berpengaruh signifikan terhadap harga saham. Hal ini dapat dilihat dari nilai signifikansi 0,841 (besar dari pada $a=0,05)$. Nilai $t_{\text {hitung }}<t_{\text {tabel }}$ yaitu $0,206<2,22$. Artinya, tidak terdapat berpengaruh signifikan Debt to Equity Ratio $\left(\mathrm{X}_{2}\right)$ secara parsial terhadap harga saham (Y). Ini berarti penelitian tidak menemukan bukti bahwa Debt to Equity Ratio $\left(\mathrm{X}_{2}\right)$ berpengaruh signifikan terhadap harga saham. Hasil penelitian ini sejalan dengan penelitian yang dilakukan oleh Ibrahim, Fenandar \& Raharja (2012) dan Sanjaya, Tomi \& Goretti (2015) yang menyatakan bahwa Debt to Equity Ratio $\left(\mathrm{X}_{2}\right)$ tidak berpengaruh signifikan terhadap harga saham $(\mathrm{Y})$.

3. Pengaruh Return on Equity $\left(\mathrm{X}_{3}\right)$ terhadap Harga Saham $(\mathrm{Y})$

Berdasarkan analisis statistik ditemukan bahwa hipotesis $\left(\mathrm{H}_{3}\right)$ diterima dan disimpulkan bahwa Return on Equity (ROE) berpengaruh signifikan terhadap harga saham. Hal ini dapat dilihat dari nilai signifikansi 0,008 (kecil dari pada $\alpha=$ $0,05)$. Nilai $t_{\text {hitung }}>t_{\text {tabel }}$ yaitu $3,286>2,22$. Artinya, terdapat berpengaruh signifikan Return on Equity $\left(\mathrm{X}_{3}\right)$ secara parsial terhadap harga saham $(\mathrm{Y})$. Ini berarti penelitian menemukan bukti bahwa Return on Equity $\left(\mathrm{X}_{3}\right)$ berpengaruh signifikan terhadap harga saham. Hasil penelitian ini sejalan dengan penelitian yang dilakukan oleh Hanum (2011) dan Sanjaya, Tomi \& Goretti (2015) yang menyatakan bahwa Return on Equity $\left(\mathrm{X}_{3}\right)$ tidak berpengaruh signifikan terhadap harga saham $(\mathrm{Y})$. 


\section{SIMPULAN}

Kesimpulan yang dapat diambil dari pengaruh Earning per Share (EPS), Debt to Equity Ratio (DER) dan Return on Equity (ROE) terhadap harga saham adalah:

1. Earning per Share (EPS) tidak berpengaruh signifikan terhadap harga saham.

2. Debt to Equity (DER) tidak berpengaruh terhadap harga saham.

3. Return on Equity (ROE) berpengaruh signifikan terhadap harga saham.

\section{DAFTAR PUSTAKA}

Brigham \& Houston. 2010. Dasar-dasar Manajemen Keuangan. Jakarta: PT Salemba Empat.

Fahmi, I. 2012. Teori Portofolio dan Analisis Investasi. Bandung: Alfabeta.

Ghozali, I. 2011. Aplikasi Analisis Multivariate Dengan Program SPSS. Semarang: Penerbit Universitas Diponegoro.

Hanum, Z. 2011. Pengaruh Return on Aset (ROA) Return on Equity (ROE) dan Earning per Share (EPS) terhadap Harga Saham pada Perusahaan Otomotif di Bursa Efek Indonesia. Jurnal Manajemen Dan Bisnis, 1(2).

http://market.bisnis.com/read/20150121/7/393242/inilah-6-manfaat-go-public bagi-perusahaan. $2015 . \quad$ Retrieved from http:/ / market.bisnis.com/read/20150121/7/393242/inilah-6-manfaat-gopublic-bagi-perusahaan.

https://www.sahamok.com/perusahaan-publik-terbuka-tbk-emiten-bei-bursa-efek indonesia/. 2017. Retrieved June 30, 2017, from https:// www.sahamok.com/perusahaan-publik-terbuka-tbk-emiten-beibursa-efek-indonesia/.

https: //www.kembar.pro/2015/07/3-keuntungan-dari-berinvestasi-saham.html. 2015. Retrieved from https: //www.kembar.pro/2015/07/3-keuntungan-dariberinvestasi-saham.html.

Ibrahim, Fenandar \& Raharja, S. 2012. Pengaruh Keputusan Investasi, Keputusan Pendanaan dan Kebijakan Dividen terhadap Nilai Perusahaan. Diponegoro Journal of Accounting, 1(2).

Jogiyanto, H. 2010. Teori Portofolio dan Analisis Investasi. Yogjakarta: BPFE.

Kasmir. 2012. Analisa Laporan Keuangan. Jakarta: PT. Raja Grafindo.

Mulia, R. A. (2019). Analisis Faktor-Faktor Yang Mempengaruhi Kualitas Laporan Keuangan Pemerintah Daerah (Studi Pada Pemerintah Kabupaten Pasaman Barat). Jurnal EL-RIYASAH, 9(1), 7-21.

Nurrohman, M. H. \& Z. 2016. Pengaruh Earning Per Share (EPS) Return Saham, Kualitas Audit dan Hasil Laba terhadap Return Saham. Diponegoo Jounal of Accounting, 2( 3).

Sanjaya, Tomi \& Goretti, M. 2015. Pengaruh Return on Equity (ROE), Debt to Equity Ratio (DER), Earning Per Share (EPS) terhadap Harga Saham. Jurnal Administrasi Dan Bisnis, 23(1).

Sartono. (2008). Manajemen Keuangan: Teori dan Aplikasi. Yogjakarta: BPFE.

Tandelilin, E. 2010. Portofolio dan Investasi: Teori dan Aplikasi. Yogjakarta: Kanisius.

Widiatmojo, S. 2005. Cara Sehat Investasi Pasar Modal. Jakarta: Elex Media Komputindo. 